Final draft of Hirvonen, N., Enwald, H., Känsäkoski, H., Eriksson-Backa, K., Nguyen, H., Huhta, A-M. \& Huvila, I. (2020) Older adults' views on eHealth services: a systematic review of scientific journal articles. International Journal of Medical Informatics, Volume 135, March 2020, 104031. https://doi.org/10.1016/j.ijmedinf.2019.104031

\title{
Older adults' views on eHealth services: a systematic review of scientific journal articles
}

\section{Introduction and objectives}

eHealth, according to the widely-cited definition of Eysenbach [1], encompasses health services and health information that are provided via the Internet and related technologies. eHealth does not only refer to technical development, but also to a state-of-mind, "an attitude, and a commitment for networked, global thinking, to improve healthcare locally, regionally, and worldwide by using information and communication technology" [1], placing focus on laypersons managing their own health [2]. eHealth strategies and services can enable patients to be active participants in medical decision making, help in health management, and provide information that can lead to a better understanding of health [1][3][4].

As eHealth is a broad concept, several kinds of services can be seen as eHealth services, including patient forums, electronic patient records, mobile health services, and self-tracking systems such as fitness wristbands, and telemedicine, considered as the oldest form of eHealth [5]. A thematic analysis by Shaw et al. [6] revealed three prominent but overlapping domains of eHealth: health in our hands (using eHealth technologies to monitor, track, and inform health), interacting for health (using digital technologies to health communication), and data enabling health (collecting, managing, and using health information).

Earlier reviews on eHealth research have focused on, for example, eHealth definitions [7], patient acceptance [8], effectiveness [9], and use of eHealth for patient engagement [10]. Feather and 
colleagues [11] reviewed research on users' experiences on psychosocial self-help eHealth interventions and found that most studies focus on the functionalities of interventions, and there is a gap in research on users' experiences. Overall, eHealth research tends to focus on system usability rather than the usefulness, purposes, benefits, or value of eHealth services to their users [12].

In the present review, we focus on the body of research that addresses people's views on consumer eHealth services. To clarify, in this review, we are not interested in studies on eHealth service effectiveness, usability, technology acceptance, or satisfaction as such and as included in earlier reviews, but rather in lay people's experiences, opinions, and thoughts about the usefulness of eHealth services, perceived benefits of use, perceived impact on life, and needs satisfaction and on the other hand, possible negative outcomes of eHealth as experienced by service users. We are also interested in how these views have been investigated, i.e., what kind of approaches and methods have been used in current research. This area of research crosses several disciplines with varying publishing practices. This review is restricted to original research articles published in scientific journals.

The review concentrates on the views of a specific age group, that is, adults aged 50 to 70 years. In the review, the term 'older adults' is used to refer to this age group, to separate them from 'younger adults' although we acknowledge that age classifications can be problematic and vary between countries and over time [13]. Often, older age is defined in relation to retirement from paid employment, typically from 60 to 65 years [13]. However, in countries with a short life expectancy, over 50 year-old adults may be seen as elderly persons [13]. The age 50 at the lower point of the age range is in line with large longitudinal projects on aging including the Health and Retirement Study (HRS) in the United States [14], the English Longitudinal Study of Ageing (ELSA) [15], and the Survey of Health, Ageing and Retirement in Europe (SHARE) [16]. The higher point of the range was set to 70 to exclude studies focusing on people suffering from the so-called geriatric giants such as frailty, sarcopenia, and cognitive impairment [17] or living in institutions or otherwise under the care of others. Overall, 'older adults', as defined in this paper, is obviously not a homogenous group 
of people but can be expected to share commonalities such as that they tend to be actively involved in working life or retired relatively recently, especially as retirement age is approaching 70 in many countries [18], and experience a higher risk of chronic diseases [19] and comorbidity problems and may need healthcare services related to those issues [20]. Most still have several years of life ahead. Previous research suggests that as a population becomes older, age has an exponential effect on digital inequalities [21][22]. Older adults are the fastest growing group of computer and Internet users [23]. Yet, at least until recently, they have been more likely to be excluded from the benefits of information and communication technologies (ICTs) [24]. This exclusion has been associated with a lack of access to digital services (first level digital divide) but also to a lack of use (second level digital divide) [25]. Even if eHealth services would be readily available, their use is encouraged or required, also those older adults who are using technologies and online services in their everyday life may experience a variety of barriers to their use ranging from issues with familiarity and trust on especially newer technology [26] to confidence in their own skills [27] or sensory, motor, or cognitive performance [28]. The aging process also involves psychological and social changes [29] that may influence the needs for or use of eHealth services.

Systematic reviews on older adults as eHealth users have placed focus on research on eHealth literacy interventions [30], the effectiveness of eHealth interventions for physical activity promotion [31], Web 2.0 applications for chronic disease management [32], barriers to adopting assistive technologies [33], and perceptions of fall prevention technologies [34]. To our knowledge, there are no previous systematic reviews on older adults' views on eHealth services.

The aim of this systematic review was to collate studies concerning older adults' views on eHealth services. The following research questions were formulated for the review:

Q1: What methods are used to study older adults' (50-70 years old) views on eHealth services?

Q2: What kind of themes emerge from the findings of the reviewed research with regard to older 
adults' views on eHealth services?

Q3: Do the reported findings vary according to the used methodological approach?

\section{Methods}

To ensure transparent reporting, the PRISMA guidelines (Preferred Reporting Items for Systematic reviews and Meta-Analyses for Protocols) for systematic reviews were followed when applicable $[35]$.

\subsection{Search strategy}

To identify relevant original scientific research articles, we performed searches from PubMed, CINAHL (EBSCO), Library, Information Science \& Technology Abstracts (LISTA, EBSCO), Academic Search Premier (EBSCO), Library and Information Science Abstracts (LISA, ProQuest), Applied Social Sciences Index and Abstracts (ASSIA, ProQuest), Computer and Information Systems Abstracts (CIS, ProQuest), and EBM Reviews (Ovid) databases in November 2015. We selected a multidisciplinary database (Academic Search Premier), databases that cover health related research (PubMed, CINAHL, EBM Reviews, ASSIA) as well as databases focused on computer and information systems sciences (CIS) and information science (LISA, LISTA) literature. The search was restricted to peer-reviewed research articles published in 2010 or later. No language or publication status restrictions were imposed at this stage.

For the final searches, the following search strategy was used as a title and abstract search: ("older adult*” OR “elderly" OR “aging” OR “ageing” OR "baby boomer*” OR senior* OR geriatric* OR “older people" OR “old people" OR “old adult*”) AND (technolog* OR ICT OR e-health OR eHealth OR "health information technology" OR HIT OR telehealth OR telemedicine OR internet OR informatics OR software OR "social media" OR web* OR mHealth OR m-Health OR "mobile health" OR “social networking site*” OR SNS OR app OR apps OR application* OR "health information 
technology" OR telehealth) AND (health* OR well-being OR wellbeing OR "well being" OR wellness OR disease* OR illness* OR sickness* OR self-management OR "self management" OR chronic OR self-care OR “self care") AND (information OR content* OR message* OR feedback OR knowledge OR communication* OR interaction OR "consumer health information")

The last set of search terms was included in order to retrieve articles that would focus on the content or usage of an eHealth service rather than its technical features. Articles were also searched manually. The following journals (published in 2010 or later) were browsed: Journal of Medical Internet Research, Journal of Aging and Health, Research on Aging, the Gerontologist, International Journal of Medical Informatics, European Journal of Ageing, Ageing International and Informatics for Health and Social Care, Information Systems Journal, Journal of the Association for Information Systems, Information \& Management, Behaviour and Information Technology, Database for Advances in Information Systems, Electronic Commerce Research and Applications, Electronic Journal of IS in Developing Countries, e-Service Journal, Information \& Organisation, Journal of Global Information Technology Management, Journal of Organisational Computing and Electronic Commerce, International Journal of Electronic Commerce, MIS Quarterly Executive, and Journal of Management Information Systems. Furthermore, some articles were found and examined by using a chaining method, i.e., by finding interesting articles at the reference lists of included articles.

\subsection{Selection process}

The search produced 3,554 references and 48 potentially relevant references were identified through manual searches and other sources (see Figure 1). After the removal of duplicates, 3,037 unique publications were identified. Their titles and abstracts were inspected. For the review, we included original, peer-reviewed, empirical research articles that focused on older adults' views on consumer eHealth services. In the review, we understand consumer e-Health services to include health related online services such as online personal health records, telehealth services, and mHealth made available for patients or consumers. Older adults are defined to be from 50 to 70 years of age. To be 
included in the review, the majority of study participants should be at this age or results reported separately for participants from this age group.

Acknowledging that the search was representative for scientific journal articles rather that conference publications and books, the review was restricted to this publication type. The search resulted in one conference publication which was excluded. Moreover, only articles written in English were included in the review.

An article was excluded from the review if one or more of the following criteria were met:

1. not published in a scientific journal, an original peer-reviewed empirical research article, or written in English

2. no consumer eHealth component (research on hospital and other health care IT systems, home measurement/monitoring/sensors, smart homes, and robots were excluded)

3. non-relevant age group; if the mean age of participants exceeded 75 years or fell below 45 years, the study was excluded

4. no users' views, opinions or experiences reported

The selection of papers was carried out in two stages. First, at least two of the authors independently inspected the abstracts and agreed whether they should be included or not. The second stage involved reviewing the included full papers $(n=245)$ against the abovementioned inclusion and exclusion criteria. If a reviewer was unsure about the inclusion of an article at stage one, it was included in the second stage. A consensus was reached in discussions. Altogether 32 scientific journal articles were included for the systematic review.

\subsection{Data extraction, synthesis, and analysis}

Once a study had been included, data was extracted using a data extraction sheet outlined for the purposes of this review. The following information was sought from each article: author identification, year of publication, bibliographic details, geographical location of the study, the aim 
or research questions of the study, sample size, methods, and main findings. Due to the diversity of used methodologies, we decided not to perform a detailed study quality assessment. Further, the results sections of the studies were analyzed with content analysis by the first author using Nvivo 11.0. The focus of the qualitative analysis was on reported views, experiences, and opinions on eHealth services. A meaning unit, that is, "the constellation of words or statements that relate to the same central meaning" [36] was considered as the unit of analysis. The coding scheme was developed in a data-driven manner although earlier literature on the topic guided the analysis. The analysis resulted in formation of categories and sub-categories.

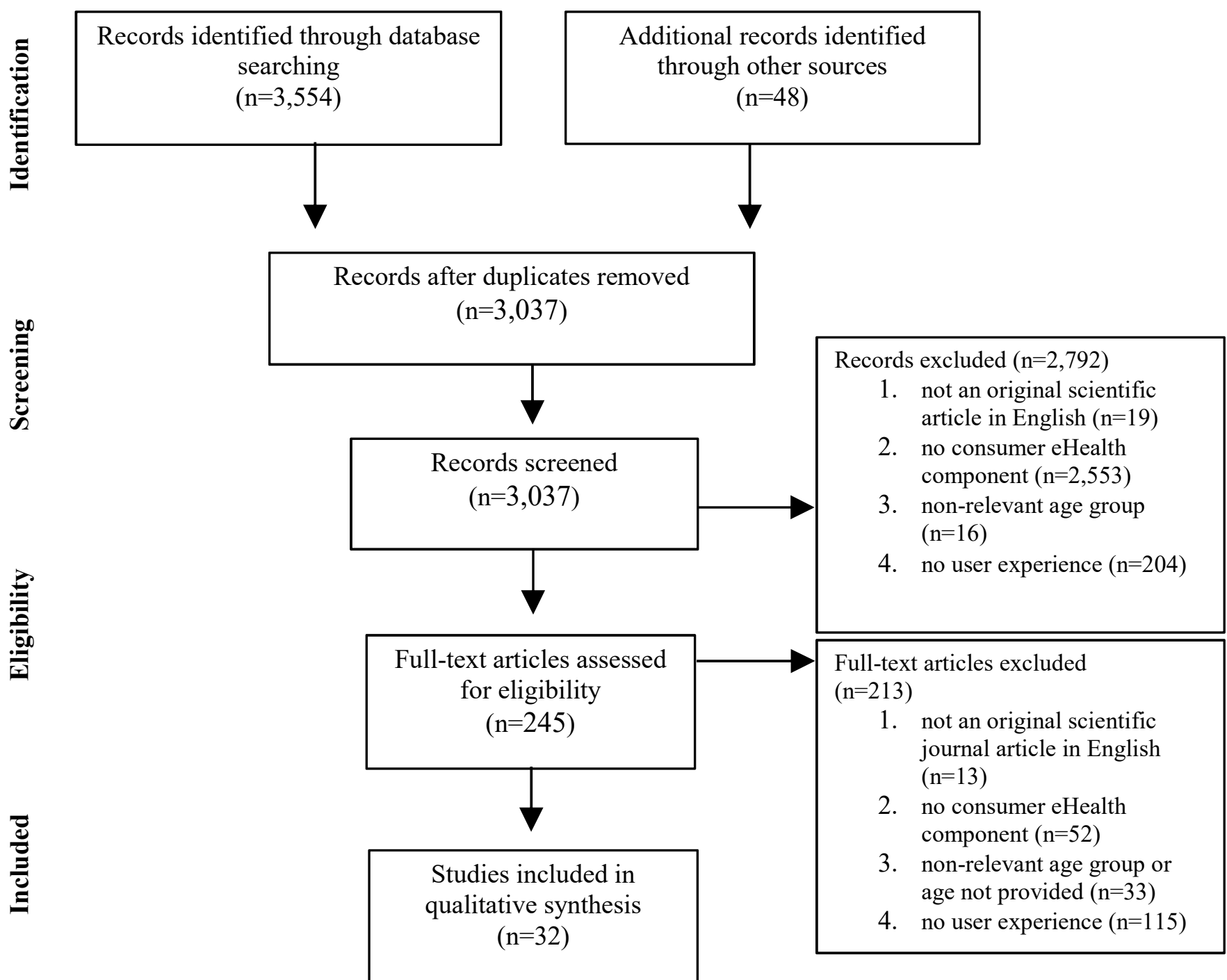


Figure 1. PRISMA flowchart of the inclusion procedure.

\section{Results}

\subsection{Characteristics of included studies}

In total, 32 articles published in 25 journals between 2011 and 2016 were included in the review (see Tables 1, 2, and 3). Half of the studies reported in the articles were conducted in North America (the US $n=15$; Canada $n=1$ ). Twelve studies represented a number of European countries including the Netherlands $(n=3)$, UK $(n=3)$, France $(n=1)$, Spain $(n=2)$, and Germany $(n=1)$. Three of the studies originated from Asia (Malaysia $n=1$, Taiwan $n=2$ ) and three from Oceania (Australia $n=2$, New Zealand $n=1$ ). Based on the first author's affiliation, the studies represented a range of disciplines including medicine, public health and health services $(n=5)$, medical, biomedical, health and visual informatics $(n=4)$, psychology and health psychology $(n=5)$, information systems, computing and engineering $(n=3)$, nursing $(n=2)$, communication $(n=3)$, information science and information management $(n=3)$, pharmacy $(n=2)$, social work $(n=1)$, social sciences $(n=1)$, gerontology $(n=1)$, and geosciences $(\mathrm{n}=1)$.

\subsection{Methods used to study older adults' views on eHealth services}

In 16 studies [37-53] the participants were generally healthy. The rest focused on patients [54], typically with specific conditions including cancer [55][56], cardiac diseases [57], substance abuse [58], asthma [59], chronic pain [60], hypertension and/or diabetes [61][62][63][64], chronic obstructive pulmonary disease [65], chronic conditions [66], and multi-morbidity [67][68]. Of the included studies, 10 applied quantitative methods (see Table 1), 14 qualitative methods (see Table 2), and 8 a mix of quantitative and qualitative methods (see Table 3) to study older adults' views on eHealth services. The number of study participants ranged from 3 to 1,266. 


\subsubsection{Quantitative methods}

Questionnaire survey was the most commonly used method to collect quantitative data on participants' views. This method was used in all quantitative (Table 1) and mixed methods studies (Table 3). Most commonly, cross-sectional data were collected with the exception of two trials [41][67] where questionnaire data about participants' views were collected from the same people at two time points. The questionnaires focused on different areas, some targeting, for example, the value of an eHealth service to its users, others investigating personal factors that may influence service use. However, the following common themes could be distinguished in the questionnaires:

1) A question or questions on the overall usefulness or value of a service were included in seven studies $[41][53][56][57][68]$. Some of the questionnaires included items on the usefulness of specific features such as the usefulness of each service function [56] or the purposes to which the tools were used [53].

2) The motivation, interest, or intentions to use a service was inquired in eight studies. The respondents were asked if they intended to look for information [42], have a test, or talk to a doctor [42], if they would use a particular website if it was made available [57], or if they intended to use a service again [53][61]. Moreover, they were inquired about their current use and attitudes towards future use of technologies [60]. The 'Interest/Enjoyment' and 'Effort/importance' subscales from the Intrinsic Motivation Inventory (IMI) were used in one study [41].

3) Study participants' satisfaction with a specific service was inquired with questions about overall satisfaction [40][53][56][67] with a service, with each service feature [56] or more specifically about particular features such as satisfaction with the appearance or attractiveness of the service [38][40][55][59][61], its comprehensibility [38][40][55][59], amount of time required, and supporting information [39], emotional support [38][55], information received [61], reliability [64], or relevance [42]. Moreover, in several studies, 
the participants were asked if they would recommend the service to others $[53][56][61][64][67]$.

4) Items about ease of use were included in ten studies $[37][39][40][41][53][56][59][64][75][67]$.

5) The perceived impact of a service was examined in ten studies. The respondents were asked about the overall perceived impact of using a service [59], whether the service had increased their knowledge [37][48][61][64], had impact on their (health) behaviour [48][53][64], emotions [41][48][57], or attitudes [41], enabled or facilitated communication $[48][53][57][64]$ or increased independence [67]. Furthermore, whether the participants could remembered the content of the service was examined in several studies [37][38][55].

6) Situational and personal factors influencing eHealth service use that were taken into account included demographic characteristics such as age [37-40][42][44][49][53][55$57][60][67]$, education [37-38][53][55-56][60], and gender [37-38][40-42][44][53][5556][60][67], competence, health literacy, knowledge, or prior experience [37-38][55$56][40-42][53][57][61][67]$, psychological factors such as locus of control [41][53], selfefficacy [53], perceived control [67-68], certainty [42], and health beliefs [61], and emotions or mood [41-42][53]. Moreover, disease or health related factors [53][55][6061][67], service availability [53][60], help or support from others [57][60], health care utilization [53], interaction with healthcare providers [60], and financial concerns [61] were enquired.

\subsubsection{Qualitative methods}

Qualitative data on user views were collected in 23 studies. Interview [39-41][45][47][49$50][52][58][60][62-66]$ was the most common method to collect qualitative data. Other methods include focus groups [43][46][51][54][62], the think-aloud method [40][59], documentation of user 
comments during a test [56], meetings [68], survey with open-ended questions [56], and diary method [49-50]. Since the data collection protocols were not described in detail in the most of the cases, it was impossible to conduct a detailed analysis of thematic similarities in the data collection of the reviewed qualitative studies.

\subsection{Key findings}

Three broad themes emerged from the content analysis of the results sections of the included articles: 1) uses of eHealth services, 2) barriers and enablers to use eHealth services, and 3) positive and negative outcomes of eHealth service use.

\subsubsection{Uses}

The reviewed studies focused on various types of eHealth services. Yet, similar self-reported uses and functionalities of eHealth services could be identified across different studies. Predominantly, eHealth services were used (or anticipated to be used) for social actions: communicating $[39][41][47][52][54][56-57][61-62][64-66]$, sharing information with others $[45-47][51-$ $54][62][65]$, to receive feedback [49][62][64] or to prepare for encounters with health professionals [54]. eHealth services were also used to enable health management [39][41][46-47][49][5254][58][60][62-66]. More specifically, based on the reviewed studies, eHealth services allow older adults to set goals [58][66], track their own behavior or symptoms [46][49][51][53-54][56][63-66], plan and schedule own actions [49][52][54][56][64], and remind about them $[43][49][54][56][58][63][64][65]$. Moreover, eHealth services provide recommendations [47][51] and help in decision-making [47][54][66], and are used for learning or seeking information on a topic [39][42-43][48-49][57][60][64]. A less apparent category was personal information management, including functions for managing data [49][52-53] and keeping information for someone else [49]. 


\subsubsection{Barriers and enablers}

Several barriers for using eHealth services were identified in the reviewed studies. Finding the content or functionality of a service irrelevant [43][47][39][41][49][53][59][63][66], lack of additional benefits from using the service [43][49-50][52-53][56][63][66], and issues with usability $[43][47][49][53][56][63][64]$ were the barriers that were mentioned most often. Comprehensibility of an eHealth service or its content [37][39-40][46-47][59], not being familiar with a specific service or its functionalities $[43][51][53][62][65]$ and thinking that a service is not "meant for me" $[40][43][51-52][65]$ were also identified as barriers for eHealth use in several studies.

Practical barriers include infrastructure and technical issues [52][60], costs [51][62], cognitive or health related issues $[43][60][63][65]$, and the time and effort needed to use a service $[41][43][50]$. Lack of prior experience [40][63], fear of making a mistake [43][63], concerns of data loss or losing a device [51][53][63], reliance on professionals [65], negative approach to technology [43][45][52], lack of help [62-63], and privacy concerns [49][52-53] can also form barriers to eHealth use.

Ease of use [39-42][44][51-53][56][59-60][64-65][67], added value provided by an eHealth service $[37][44][58][60][50-51]$, own interest and needs [45][47][63], comprehensibility [37][40][47][59], and relevant content or functionality [42][44][49][53] were identified as enablers of eHealth use. Moreover, own capability [43][50][52], service attractiveness [40][43][59], having the needed technical equipment [56], prior experience [56], help or support from others [53][58][65], and being aware of the service [56] can help make eHealth service use possible.

\subsubsection{Positive and negative outcomes}

Positive outcomes identified in the reviewed studies connected to overall positive conceptions of a service, and impact on knowledge and health management. Based on the findings, eHealth services are often perceived as useful and relevant [37][43][53][56-57][59], and older adults tend to be satisfied with the service under study [38-40][44][50][53][55][58][65][67]. 
Based on the reviewed research, eHealth services may help increase knowledge [37-38][42-43][4849][54][59-60][64], increase awareness of own health [37][41][53-54][59][62][65-66], and impact thinking skills [50]. They can help in managing health [41][53-54][56][59-60][62][64-65][67] and in decision-making [45][47][52][54], improve communication with healthcare professionals [5354][57-58] and provide insight with professionals' perspectives [54]. Further, they can provide emotional support [38][62][67], positive emotions [42-43][50], reassurance [48], and increase confidence [50][65], a sense of security [53][62], of continuity of care [53][65], and of control and empowerment [53-54][67] for older adults.

Based on the reviewed studies, the use of an eHealth service may result in subsequent information seeking [54] or seeking contact with health professionals [42][48], and help in managing information [53]. Moreover, eHealth use may result in increased intentions to behavior change [42][48], change in actual health behavior [48][56][58][62][64], and have an overall positive impact in life [41].

The anticipated or actual negative outcomes of using eHealth services that were identified in the studies focused on emotions. These included overall negative emotional influences such as anxiety and stress [41-43][48][50][53-54][57][66], isolation, lack of human interaction [50][60], infringement of privacy [53-54], and being worried about breaking the service [62]. Moreover, judgmental language and tone [54][66], distrust on data or information [43][62][66], subjective interpretation of information [54][66], and mistakes and inconsistencies in data [54] were seen as troublesome. The possibility of data loss or fallibility [43][53][62-63], time and effort needed to use the system [43][60][65-66], and technical issues [43] were identified as practical negative outcomes of eHealth use. Moreover, eHealth service use was expected to possibly form a strain on patientprovider dialogue [48][54].

\subsection{Findings by used methods}


Finally, the findings were investigated by the type of method used to study older adults' views on eHealth services (see Table 4). Findings on the types of eHealth service uses were reported more often in qualitative studies when compared to those using quantitative or mixed methods. Most studies, regardless of method, reported positive outcomes of using eHealth services. In turn, barriers to eHealth service use were reported in only two and negative outcomes in four of the eleven studies using quantitative methods. Studies using qualitative methods reported barriers and negative outcomes clearly more frequently (Figure 2).

Figure 2. Themes identified from the findings of the reviewed research by the methodological approach used to study older adults' views on eHealth services.

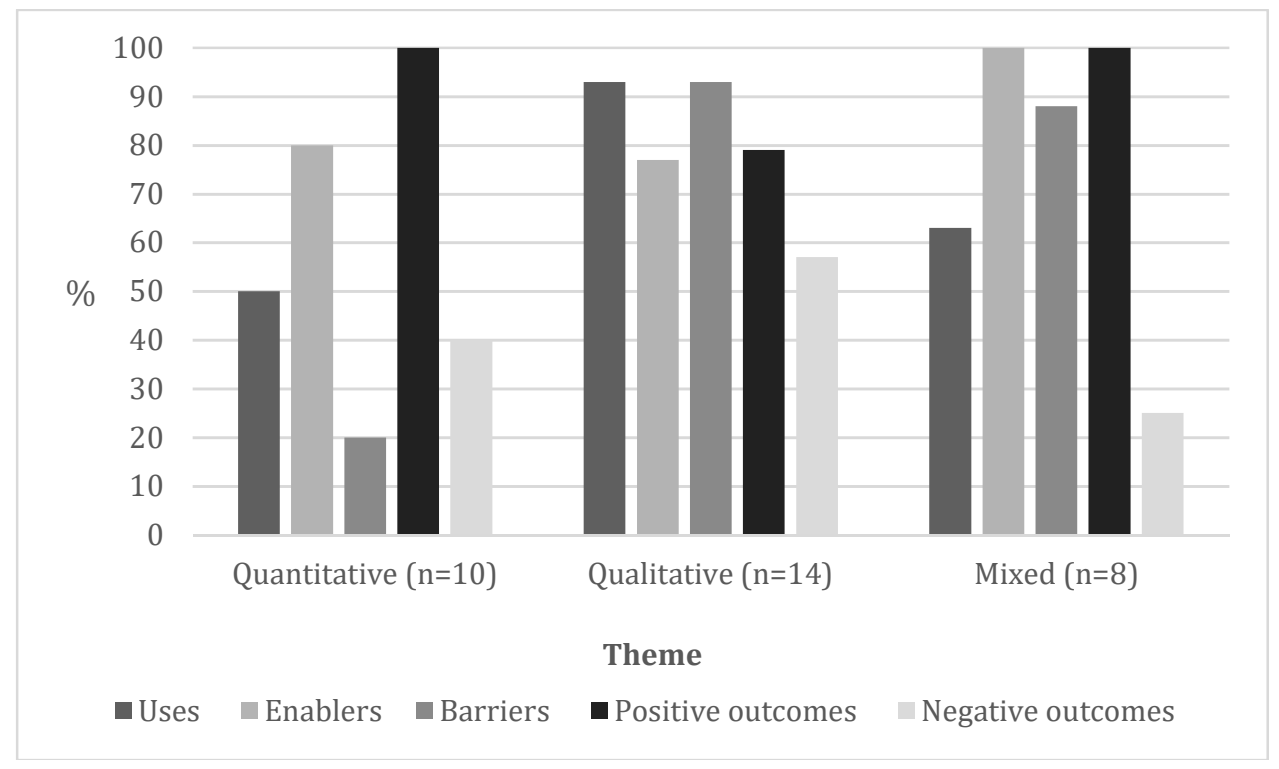

Table 4. Themes and sub-themes identified from the findings of the reviewed research by methodological approach to study older adults' views on eHealth services.

\begin{tabular}{|c|c|c|c|}
\hline \multirow[b]{2}{*}{ Theme and sub-themes } & \multicolumn{3}{|c|}{ Methodological approach } \\
\hline & $\begin{array}{l}\text { Quantitative (n=10) } \\
{[37][38][42][44][48][53][55][} \\
57][61][67]\end{array}$ & $\begin{array}{l}\text { Qualitative (n=14) } \\
{[43][45][46][47][49][50][51][52][54][58]} \\
{[62][63][65][66]}\end{array}$ & $\begin{array}{l}\text { Mixed }(n=8) \\
{[39][40][41][56][59][60][64][68]}\end{array}$ \\
\hline Uses / reported in ( $\mathrm{n}$ of studies) & 5 & 13 & 5 \\
\hline $\begin{array}{l}\text { Health management } \\
\text { Health management in general } \\
\text { Seeking information / learning } \\
\text { Setting goals }\end{array}$ & $\begin{array}{l}{[53][61]} \\
{[42][48][57]}\end{array}$ & $\begin{array}{l}{[46][47][49][52][54][58][62][63][65][66]} \\
{[43][49]} \\
{[58][66]}\end{array}$ & $\begin{array}{l}{[39][41][60][64]} \\
{[39][60][64]} \\
-\end{array}$ \\
\hline
\end{tabular}




\begin{tabular}{|c|c|c|c|}
\hline $\begin{array}{l}\text { Planning and scheduling } \\
\text { Tracking own behavior/symptoms } \\
\text { Receiving reminders } \\
\text { Help in decision-making } \\
\text { Recommendations }\end{array}$ & $\begin{array}{l}- \\
{[53]} \\
- \\
- \\
-\end{array}$ & $\begin{array}{l}{[49][52][54]} \\
{[46][49][51][54][63][65][66]} \\
{[43][49][54][58][63][65]} \\
{[47][54][66]} \\
{[47][51]}\end{array}$ & $\begin{array}{l}{[56][64]} \\
{[56][64]} \\
{[56][64]} \\
- \\
-\end{array}$ \\
\hline $\begin{array}{l}\text { Social uses } \\
\text { Communication } \\
\text { Sharing information with others } \\
\text { Receiving feedback } \\
\text { Preparing for encounters }\end{array}$ & $\begin{array}{l}{[57][61]} \\
{[53]} \\
- \\
-\end{array}$ & $\begin{array}{l}{[48][53][55][59][63][66][67]} \\
{[46][47][48][52][53][55][63][66]} \\
{[50][63]} \\
{[55]}\end{array}$ & $\begin{array}{l}{[40][42][57][65]} \\
- \\
{[65]} \\
-\end{array}$ \\
\hline $\begin{array}{l}\text { Personal information management } \\
\text { Managing data } \\
\text { Keeping information for someone else }\end{array}$ & $\begin{array}{l}{[53]} \\
-\end{array}$ & $\begin{array}{l}{[50][53]} \\
{[50]}\end{array}$ & - \\
\hline Barriers / reported in ( $\mathrm{n}$ of studies) & 2 & 13 & 7 \\
\hline $\begin{array}{l}\text { Non-familiarity } \\
\text { Lack of additional benefits from use } \\
\text { Lack of relevant content or functionality } \\
\text { Infra, technical issues } \\
\text { Cognitive or health issues } \\
\text { Lack of prior experience } \\
\text { Trust, privacy and security concerns } \\
\text { "Not for me" } \\
\text { Costs } \\
\text { Approach to technology } \\
\text { Lack of help from others } \\
\text { Usability issues } \\
\text { Time and effort } \\
\text { Comprehensibility } \\
\text { Fear of making a mistake } \\
\text { Concerns on data loss/loss of device } \\
\text { Reliance on professionals } \\
\text { Not wanting to take responsibility on } \\
\text { decision-making }\end{array}$ & $\begin{array}{l}{[53]} \\
{[53]} \\
{[53]} \\
- \\
- \\
- \\
{[53]} \\
- \\
- \\
- \\
- \\
{[53]} \\
- \\
{[37]} \\
- \\
{[53]} \\
- \\
-\end{array}$ & $\begin{array}{l}{[44][52][63][66]} \\
{[44][50][51][53][64][67]} \\
{[44][48][50][64][67]} \\
{[53]} \\
{[44][64][66]} \\
{[64]} \\
{[46][50][53]} \\
{[44][51][52][53][66]} \\
{[52][63]} \\
{[44][46][53][52]} \\
{[63][64]} \\
{[44][48][64][50]} \\
{[44][51]} \\
{[44][47][48]} \\
{[44][64]} \\
{[64][52]} \\
{[66]} \\
{[44]}\end{array}$ & $\begin{array}{l}- \\
{[57]} \\
{[40][42][60]} \\
{[61]} \\
{[61]} \\
{[41]} \\
{[41]} \\
- \\
- \\
- \\
- \\
{[57][65]} \\
{[42]} \\
{[40][41][60]} \\
- \\
- \\
- \\
-\end{array}$ \\
\hline Enablers / reported in (n of studies) & 8 & 10 & 8 \\
\hline $\begin{array}{l}\text { Being aware of the service } \\
\text { Added value } \\
\text { Help or support from others } \\
\text { Relevant content or functionality } \\
\text { Ease of use } \\
\text { Comprehensibility } \\
\text { Interest and needs } \\
\text { Capability } \\
\text { Service attractiveness } \\
\text { Having the technical equipment } \\
\text { Prior experience, familiarity }\end{array}$ & $\begin{array}{l}- \\
{[37][44]} \\
{[53]} \\
{[42][53]} \\
{[37][44][53][65][67]} \\
{[37]} \\
{[44]} \\
- \\
- \\
- \\
-\end{array}$ & $\begin{array}{l}- \\
{[43][47][50][51][58]} \\
{[58][65]} \\
{[49][50]} \\
{[51][52][65]} \\
{[47]} \\
{[43][50][52][63]} \\
{[43][49]} \\
- \\
- \\
{[45][49][51]}\end{array}$ & $\begin{array}{l}{[56]} \\
{[60]} \\
- \\
- \\
{[39][40][41][56][59][60][64]} \\
{[40][59][68]} \\
- \\
- \\
{[40][59]} \\
{[56]} \\
{[56]}\end{array}$ \\
\hline $\begin{array}{l}\text { Positive outcomes / reported in ( } \mathrm{n} \text { of } \\
\text { studies) }\end{array}$ & 10 & 11 & 8 \\
\hline $\begin{array}{l}\text { Overall usefulness or relevance } \\
\text { Increased knowledge } \\
\text { Increased awareness } \\
\text { Impact in thinking skills } \\
\text { Insight into providers' perspectives } \\
\text { Improved commun. w. professionals } \\
\text { Seeking contact w. professionals } \\
\text { Emotional support } \\
\text { Positive emotional influence } \\
\text { Satisfaction, enjoyment } \\
\text { Increased control and empowerment } \\
\text { Increased confidence } \\
\text { Sense of security } \\
\text { A sense of continuity of care } \\
\text { Enhanced health management } \\
\text { Help in decision-making } \\
\text { Increased intentions } \\
\text { Behaviour change }\end{array}$ & $\begin{array}{l}{[37][53][57]} \\
{[37][42][48][53]} \\
{[37][53][61]} \\
- \\
- \\
{[53][57]} \\
{[42][48]} \\
{[38][55]} \\
{[42][48]} \\
{[38][44][53][55][67]} \\
{[53][67]} \\
{[53]} \\
{[53]} \\
{[53]} \\
{[53][67][61]} \\
- \\
{[42]} \\
{[48]}\end{array}$ & $\begin{array}{l}{[43][66]} \\
{[43][49][54]} \\
{[54][62][65][66]} \\
{[50]} \\
{[54]} \\
{[54][58]} \\
- \\
{[62]} \\
{[43][50]} \\
{[50][58][65]} \\
{[54]} \\
{[50][65]} \\
{[62]} \\
{[65]} \\
{[54][62][65]} \\
{[47][45][52][54]} \\
- \\
{[58][62]}\end{array}$ & $\begin{array}{l}{[41][56][59][68]} \\
{[59][60][64]} \\
{[41][59]} \\
- \\
- \\
- \\
- \\
- \\
- \\
{[39][40][68]} \\
- \\
- \\
- \\
- \\
{[41][49][56][59][60][64]} \\
- \\
- \\
{[56][64]}\end{array}$ \\
\hline
\end{tabular}




\begin{tabular}{|c|c|c|c|}
\hline $\begin{array}{l}\text { Information seeking } \\
\text { Overall positive impact } \\
\text { Help in information management } \\
\text { Saving time }\end{array}$ & $\begin{array}{l}{[42]} \\
- \\
- \\
{[53]}\end{array}$ & $\begin{array}{l}{[54]} \\
- \\
{[49]} \\
-\end{array}$ & $\begin{array}{l}- \\
{[41]} \\
-\end{array}$ \\
\hline $\begin{array}{l}\text { Negative outcomes / reported in (n of } \\
\text { studies) }\end{array}$ & 4 & 8 & 2 \\
\hline Invasion of privacy & {$[53]$} & {$[69][54]$} & - \\
\hline Possibility of data loss or fallibility & {$[53]$} & {$[43][62][63]$} & - \\
\hline Negative emotional influence & {$[42][48][53][57]$} & {$[43][50][54][66]$} & {$[41]$} \\
\hline Isolation, lack of human interaction & - & {$[50]$} & {$[60]$} \\
\hline Time and effort & - & {$[43][65][66]$} & {$[60]$} \\
\hline Judgmental language and tone & - & {$[54][66]$} & - \\
\hline Distrust of data/information & - & {$[43][62][66]$} & - \\
\hline Mistakes and inconsistencies & - & {$[54]$} & - \\
\hline Subjective interpretation of information & - & {$[54][66]$} & - \\
\hline Technical problems & - & {$[54]$} & - \\
\hline Strain on patient-provider dialogue & [48] & [54] & - \\
\hline
\end{tabular}

\section{Discussion}

This systematic review of articles on research on older adults' views on eHealth services published in scientific journals shows that this topic is studied across several disciplines ranging from medical sciences to information and information systems sciences. Both qualitative and quantitative methods are used to investigate older adults' experiences and perceptions of eHealth services, questionnaires and interviews being the most often used approaches to collect data. Both generally healthy individuals and specific patient groups have been studied, as well as specific services and general experiences and opinions. The reviewed studies' findings emphasize positive outcomes of eHealth service use. Findings on negative outcomes and barriers, in turn, are reported mainly in qualitative studies.

The findings have similarities with those of previous reviews, indicating that in current research relatively little attention is paid to examine user experiences [11], the purposes and benefits of eHealth services [12] or their long-term value for people, rather than immediate actions at the moment of interacting with a service [30]. A common trait in research on technology adoption and use is its focus on specific technologies and pieces of software rather than investigating the broad sociotechnical context within which their users live [69]. Benefits, value, and usefulness are not software features, but constructed in the interaction of a user and a system (see [70] based on [71][72]). Therefore, they may be difficult to study with traditional methods and theoretical frameworks developed for and 
focused on technology evaluation. It can be argued that even standard usability evaluation methods are usually not relevant if they are taken outside of their "culture of use" [73], and that the design of a system should be based on a comprehensive understanding of its users and their contexts [74] instead of attempting to investigate technology use in isolation [75].

The eHealth services that were investigated in the reviewed studies were used for communication, health management, and, to a lesser extent, for personal information management. This categorization resembles the one of Shaw et al. [6] who found three overlapping domains of eHealth: health in our hands, interacting for health, and data enabling health. Based on this review, existing research on older adults as eHealth service users focuses on social uses and health management rather than personal information management.

The findings of the reviewed studies were arranged in three broad themes: uses of an eHealth service, enablers and barriers to using them, and the positive and negative outcomes of their use. Specifically in the quantitative studies, there seems to be a so-called positivity bias: users' satisfaction with a given eHealth service is reported in most studies whereas negative outcomes and reasons for not using a service are either not studied or reported. Unsurprisingly, some of the reported outcomes and concerns have been noted in earlier reviews (e.g., [32][33][34]).

More attention should be paid on the ways people use eHealth services within their daily lives and the impact this use has, including the possible negative consequences. By broadening the perspective from the context of specific systems to encompass the wider life worlds of people, we may be better able to explain findings on, for example, the second level 'grey digital divide', that is, the lack of digital service use [25]. For instance, as identified in several of the reviewed studies, the use of eHealth services may involve negative emotions and lead, from the users' perspective, to adverse consequences such as isolation and loss of privacy. If the impact of eHealth is anticipated to be negative, it can lead to system non-use, independent of system features. 


\section{Limitations}

The search strategy for this review was originally formulated to identify research where the focus would be placed especially on users views on the content and usage of an eHealth service, not its technical features. We are aware that with this strategy, there may be relevant references relating to views on other features and types of systems that were not retrieved. Naturally, we acknowledge that the represented fields may not be completely covered in this review as the used databases did not necessarily contain references to all key publications. We did not, for instance, include conference proceedings databases in our systematic search, thus leaving out a considerable amount of potentially relevant texts. Yet, we are confident that the articles that were found are reasonably representative of the body of scientific journal articles published within this multi-disciplinary area of research with varying practices and venues of publishing findings, and consequently, of what is known about older adults and their views of the usefulness and outcomes of eHealth services.

\section{Conclusions}

In the present systematic review, we focused on the body of research that addresses older adults' views on eHealth services. Based on the review, the theme has been studied across disciplines, study populations, in connection to different types of eHealth services, and with a variety of methods. This variability can help provide a rich picture of the issues older adults may face when using eHealth services. At the same time, however, it is difficult to draw conclusions from this heterogeneous body of research.

To understand why older adults are likely to be excluded from the benefits of information and communication technologies [11] we need to understand their views on the issue. Based on this review, eHealth service use can involve positive outcomes but also actual or anticipated negative consequences to their users. These are not software features but socially constructed in the interaction of a user and a system [70] (based on [71][72]). We invite further research on the usefulness of 
eHealth services for their users to accompany the large body of research on service usability. Moreover, there is a call for research that examines technology use as part of people's everyday activities. The themes identified from the findings of the reviewed research can be used to diversify the approaches typically taken in, for example, participatory design of eHealth services. Practitioners should take into account the review's findings by acknowledging the diverse reasons for eHealth service non-use.

\section{Acknowledgements}

This work was supported by the Academy of Finland [grant number 287084].

\section{References}

[1] Eysenbach, G. (2001) What is e-health? Journal of Medical Internet Research 3(2), e20. http://www.jmir.org/2001/2/e20/

[2] Hyppönen, H., Faxvaag, A., Gilstad, H., Hardardottir, G.A., Jerlvall, L., Kangas, M., Koch, S., Nøhr, C., Pehrsson, T., Reponen, J., Walldius, Å. \& Vimarlund, V. (2013) Nordic eHealth Indicators: Organisation of research, first results and the plan for the future. TemaNord 522, Nordic Council of Ministers 2013, ISBN 978-92-893-2526-4. http://dx.doi.org/10.6027/TN2013-522

[3] Holmström, I. \& Röing, M. (2010) The relation between patient-centeredness and patient empowerment: A discussion on concepts. Patient Education and Counseling 79(2), 167-72.

[4] Santana, S., Lausen, B., Bujnowska-Fedak, M., Chronaki, C., Prokosch, H. \& Wynn, R. (2011) Informed citizen and empowered citizen in health: results from an European survey. BMC Family Practice 12(20).

[5] Rooij, van T. \& Marsh, S. (2016) eHealth: Past and future perspectives. Personalized Medicine 13(1), 57-70. 
[6] Shaw, T., McGregor, D., Brunner, M., Keep, M., Janssen, A., \& Barnet, S. (2017) What is eHealth (6)? Development of a conceptual model for eHealth: qualitative study with key informants. Journal of Medical Internet Research 19(10), e324. DOI: 10.2196/jmir.8106 [7] Oh, H., Rizo, C., Enkin, M. \& Jadad, A. (2005) What Is eHealth? (3) A systematic review of published definitions. Journal of Medical Internet Research 7(1), e1.

[8] Calvin, K.L. \& Ben-Tzion, K. (2009) A systematic review of patient acceptance of consumer health information technology. Journal of the American Medical Informatics Association 16(4), $550-560$.

[9] Elbert, N. J., van Os-Medendorp, H., van Renselaar, W., Ekeland, A. G., Hakkaart-van Roijen, L., Raat, H., Nijsten, T. \& Pasmans, S. (2014) Effectiveness and cost-effectiveness of eHealth interventions in somatic diseases: a systematic review of systematic reviews and meta-analyses. Journal of Medical Internet Research 16(4), e110.

[10] Barello, B., Triberti, S., Graffigna, G., Libreri, C., Serino, S., Hibbard, J., \& Riva, G. (2015) eHealth for patient engagement: a systematic review. Frontiers in Psychology 6, 2013. doi: 10.3389/fpsyg.2015.02013

[11] Feather, J. S., Howson, M., Ritchie, L., Carter, P. D., Parry, D. T. \& Koziol-McLain, J. (2016) Evaluation methods for assessing users' psychological experiences of web-based psychosocial interventions: a systematic review. Journal of Medical Internet Research 18(6), e181.

[12] Mair, F. \& Whitten, P. (2000) Systematic review of studies of patient satisfaction with telemedicine. BMJ 320(7248), 1517-1520.

[13] World Health Organization. Definition of an older or elderly person. Geneva, Switzerland: WHO; 2010. http://www.who.int/healthinfo/survey/ageingdefnolder/en/index.html (Access date 22nd November 2010)

[14] The Regents of the University of Michigan (2017) Health and Retirement Study. http://hrsparticipants.isr.umich.edu 
[15] The Institute for Fiscal Studies (2011) English Longitudinal Study of Ageing. https://www.elsaproject.ac.uk/about-ELSA

[16] SHARE-ERIC (2017) Survey of Health, Ageing and Retirement in Europe. http://www.shareproject.org/

[17] Morley, J. E. (2017) The New Geriatric Giants. Clinics in Geriatric Medicine 33(3), xi-xii.

[18] Scharn, M., Sewdas, R., Boot, C. R. L., Huisman, M., Lindeboom, M., \& van der Beek, A. J.

(2018) Domains and determinants of retirement timing: A systematic review of longitudinal studies.

BMC Public Health 18, 1083. DOI: 10.1186/s12889-018-5983-7

[19] U.S. Department of Health and Human Services. 2020 Topics and Objectives: Older adults. https://www.healthypeople.gov/2020/topics-objectives/topic/older-adults

[20] Wildenbos, GA, Maasri, K, Jaspers, M \& Peute, L (2018). Older adults using a patient portal: registration and experiences, one year after implementation. Digital Health 4: 1-9. DOI: $10.1177 / 2055207618797883$

[21] Friemel, T. N. (2014) The digital divide has grown old: determinants of a digital divide among seniors. New Media \& Society 18(2). DOI: 10.1177/1461444814538648

[22] Smith, A. (2014) Older adults and technology use. Washington, DC: Pew Research Internet Project. http://www.pewinternet.org/2014/04/03/older-adults-and-technology-use/

[23] Heart, T. \& Kalderon, E. (2013) Older adults: are they ready to adopt health related ICT? International Journal of Medical Informatics 82, e209-e231.

[24] Cotten, S. R., Anderson, W. A., \& McCullough, B. M. (2012) The impact of ICT use on loneliness and contact with others among older adults. Gerontechnology 11(2), 161-165.

[25] Chesser, A., Burke, A., Reyes, J. \& Rohrberg, T. (2015) Navigating the digital divide: a systematic review of eHealth literacy in underserved populations in the United States. Informatics for Health \& Social Care, 1-19. 
[26] Fischer, S. H., David, D., Crotty, B. H., Dierks, M. \& Safran, C. (2014) Acceptance and use of health information technology by community-dwelling elders. International Journal of Medical Informatics 83, 624-635.

[27] Lee, B., Chen, Y. \& Hewitt, L. (2011) Age differences in constraints encountered by seniors in their use of computer and the internet. Computers in Human Behavior 27, 1231-1237. [28] Fletcher, J. \& Jensen, R. (2015) Overcoming barriers to mobile health technology use in the aging population. Online Journal of Nursing Informatics (OJNI) 19(3). http://www.himss.org/ojni [29] Wrzus, C., Hänel, M., Wagner, J. \& Neyer, F. J. (2013) Social network changes and life events across the life span: a meta-analysis. Psychological Bulletin 139(1), 53-80.

[30] Watkins, I. \& Xie, B. (2014) eHealth literacy interventions for older adults: a systematic review of the literature. Journal of Medical Internet Research 16(11), e225.

[31] Muellmann, S., Forberger, S., Möllers, T., Zeeb, H., \& Pischke, C. R. (2016) Effectiveness of eHealth interventions for the promotion of physical activity in older adults: a systematic review protocol. Systematic Reviews 5, 47.

[32] Stellefson, M., Chaney, B., Barry, A. E., Chavarria, E., Tennant, B., Walsh-Childers, K. Sriram, P. S., Zagora, J. (2013) Web 2.0 chronic disease self-management for older adults: a systematic review. Journal of Medical Internet Research 15(2), e35.

[33] Yusif, S., Soar, J. \& Hafeez-Baig, A. (2016) Older people, assistive technologies, and the barriers to adoption: A systematic review. International Journal of Medical Informatics 94, $112-$ 116.

[34] Hawley-Hague, H., Boulton, A., Hall, A., Pfeiffer, K. \& Todd, C. (2014) Older adults' perceptions of technologies aimed at falls prevention, detection or monitoring: A systematic review. International Journal of Medical Informatics 83(6), 416-426 
[35] Moher, D., Liberati, A., Tetzlaff, J., Altman, D. G. \& the PRISMA Group (2009) Preferred Reporting Items for Systematic Reviews and Meta-Analyses: the PRISMA statement. PLoS Medicine 6(6), e1000097. doi:10.1371/journal.pmed1000097

[36] Graneheim, U. H. \& Lundman, B. (2004) Qualitative content analysis in nursing research: concepts, procedures and measures to achieve trustworthiness. Nurse Education Today 24, 105112.

[37] Ali, N. M., Shahar, S., Kee, Y. L., Norizan, A. R., \& Noah, S. A. (2012) Design of an interactive digital nutritional education package for elderly people. Informatics for Health and Social Care 37(4), 217-29.

[38] Bol, N., van Weert, J. C. M., de Haes, H. C. J. M., Loos, E. F., de Heer, S., Sikkel, D., \& Smets, E. M. A. (2014) Using cognitive and affective illustrations to enhance older adults' website satisfaction and recall of online cancer-related information. Health Communication 29(7), 678-688. [39] Chun, Y. J. \& Patterson, P. E. (2012) A usability gap between older adults and younger adults on interface design of an Internet-based telemedicine system. Work: a journal of prevention, assessment, and rehabilitation 41(Supplement 1), 349-352.

[40] Cristancho-Lacroix, V., Moulin, F., Wrobel, J., Batrancourt, B., Plichart, M., De Rotrou, J., Cantegreil-Kallen, I. \& Rigaud, A. S. (2024) A web-based program for informal caregivers of persons with Alzheimer's disease: an iterative user-centered design. Journal of Medical Internet Research Research Protocols 3(3), e46.

[41] Dhillon, J.S., Wünsche, B. \& Lutteroth, C. (2016) Designing and evaluating a patient-centred health management system for seniors. Journal of Telemedicine and Telecare 22(2), 96-104. doi: https://doi.org/10.1177/1357633X15586082

[42] Dillard, A. J \& Main, J. L. (2013) Using a health message with a testimonial to motivate colon cancer screening: associations with perceived identification and vividness. Health Education \& Behavior 40(6), 673-682. 
[43] Grindrod, K. A., Li, M., \& Gates, A. (2014) Evaluating user perceptions of mobile medication management applications with older adults: a usability study. JMIR mHealth and uHealth 2(1), e11. [44] Hwang, Y.-C. (2011) Study on healthcare support e-service design for senior citizens. Journal of Computers 6(3), 397-403.

[45] Kutz, D., Shankar, K. \& Connelly, K. (2013) Making sense of mobile- and web-based wellness information technology: cross-generational study. Journal of Medical Internet Research 15(5), e83. [46] Le, T., Reeder, B., Yoo, D., Aziz, R., Thompson, H.J., \& Demiris, G. (2015) An evaluation of wellness assessment visualizations for older adults. Telemedicine and e-Health 21(1), 9-15.

[47] Martin-Hammond, A. M., Abegaz, T., \& Gilbert, J. E. (2015) Designing an over-the-counter consumer decision-making tool for older adults. Journal of Biomedical Informatics 57, 113-123. [48] Medlock, S., Eslami, S., Askari, M., Sent, D., de Rooij, S. E., \& Abu-Hanna, A. (2013) The consequences of seniors seeking health information using the internet and other sources. Studies in Health Technology and Informatics 192, 457-60.

[49] Price, M. M , Pak, R., Mueller, H. \& Stronge, A. (2013) Older adults' perceptions of usefulness of personal health records. Universal Access in the Information Society 12(2), 191-204.

[50] Walker, J. E., Thompson, K. E. \& Oliver, A. I. (2014) Maintaining cognitive health in older adults: Australians' experience of targeted computer-based training, using the Brain Fitness Program. Physical \& Occupational Therapy in Geriatrics 32(4), 397-413.

[51] Watkins, I. \& Xie, B. (2015) Older adults' perceptions of using iPads for improving fruit and vegetable intake: an exploratory study. Care Management Journal 16(1).

[52] Young, R., Willis, E., Cameron, G., \& Geana, M. (2014) “Willing but unwilling”: attitudinal barriers to adoption of home-based health information technology among older adults. Health Informatics Journal 20(2), 127-135

[53] Zettel-Watson, L. \& Tsukerman, D. (2016) Adoption of online health management tools among healthy older adults: an exploratory study. Health Informatics Journal 22(2), 171-183 
[54] Woods, S. S., Schwartz, E., Tuepker, A., Press, N. A., Nazi, K. M., Turvey, C. L. \& Nichol, W. P. (2013) Patient experiences with full electronic access to health records and clinical notes through the My HealtheVet personal health record pilot: qualitative study. Journal of Medical Internet Research 15(3), e65.

[55] Bol, N., Smets, E.M., Rutgers, M.M., Burgers, J.A., de Haes, H.C., Loos, E.F. \& van Weert, J.C. (2013) Do videos improve website satisfaction and recall of online cancer-related information in older lung cancer patients? Patient Education and Counseling 92(3), 404-12.

[56] Hong, Y., Goldberg, D., Dahlke, D. V., Ory, M. G., Cargill, J. S., Coughlin, R., Hernandez, E., Kellstedt, D. K. \& Peres, S. C. (2014) Testing usability and acceptability of a web application to promote physical activity (iCanFit) among older adults. Journal of Medical Internet Research 1(1), e2.

[57] Jones, J., Cassie, S., Thompson, M., Atherton, I., \& Leslie, S.J. (2014) Delivering healthcare information via the internet: cardiac patients' access, usage, perceptions of usefulness, and web site content preferences. Telemedicine and e-Health 20(3), 223-7.

[58] Brusoski, M. \& Rosen, D. (2015) Health promotion using tablet technology with older adult African American methadone clients: a case study. Journal of Technology in Human Services 33(2), $119-132$.

[59] Burns, P., Jones, S. C., Iverson, D., \& Caputi, P. (2015) Usability testing of AsthmaWise with older adults. CIN: Computers, Informatics, Nursing 31(5), 219-226.

[60] Currie, M., Philip, L.J., \& Roberts, A. (2015) Attitudes towards the use and acceptance of eHealth technologies: a case study of older adults living with chronic pain and implications for rural healthcare. BMC Health Services Research 15, 162.

[61] Lam, A. (2011) Practice innovations: delivering medication therapy management services via videoconference interviews. Consultant Pharmacist 26(10), 764-73. 
[62] Lu, J.F., Chi, M.J., \& Chen, C.M. (2013) Advocacy of home telehealth care among consumers with chronic conditions. Journal of Clinical Nursing 23(5-6): 811-9.

[63] Scheibe, M., deReichelt, J., Bellmann, M. \& Kirch, W. (2015) Acceptance factors of mobile apps for diabetes by patients aged 50 or older: a qualitative study. Journal of Medical Internet Research 4(1), e1.

[64] Young, L. B., Foster, L., Silander, A., \& Wakefield, B. J. (2011) Home telehealth: patient satisfaction, program functions, and challenges for the care coordinator. Journal of Gerontological Nursing 37(11), 38-46.

[65] Williams, V., Price, J., Hardinge, M., Tarassenko, L. \& Farmer, A. (2014) Using a mobile health application to support self-management in COPD: a qualitative study. British Journal of General Practice 64(624), e392-400.

[66] Ancker, J.S., Witteman, H.O., Hafeez, B., Provencher, T., Van de Graaf, M. \& Wei, E. (2015) You get reminded you're a sick person: personal data tracking and patients with multiple chronic conditions. Journal of Medical Internet Research 17(8): e202.

[67] Mira, J. J., Navarro, I., Botella, F., Borrás, F., Nuño-Solinís, R., Orozco, D., Iglesias-Alonso, F., Pérez-Pérez, P., Lorenzo, S. \& Toro, N. (2014) A Spanish pillbox app for elderly patients taking multiple medications: randomized controlled trial. Journal of Medical Internet Research 16(4), e99. [68] Mira, J. J., Guilabert, M., Carrillo, I., Fernández, C., Vicente, M. A., Orozco-Beltrán, D. \& GilGuillen, V. F. (2015) Use of QR and EAN-13 codes by older patients taking multiple medications for a safer use of medication. International Journal of Medical Informatics 84(6), 406-12. [69] Kim, Y., \& Crowston, K. (2011) Technology adoption and use theory review for studying scientists' continued use of cyber-infrastructure. Proceedings of the American Society for Information Science and Technology 48 (1), 1-10. DOI: 10.1002/meet.2011.14504801197 
[70] Nocera, J. A., Dunckley, L. \& Sharp, H. (2007) An approach to the evaluation of usefulness as a social construct using technological frames. International Journal of Human-Computer Interaction 22(1-2), 153-172.

[71] Pinch, T. J. \& Bijker, W. E. (1987) The social construction of facts and artefacts: or how the sociology of science and the sociology of technology might benefit each other. In Bijker, W. E.; Hughes, T. P. \& Pinch, T. J. (Eds.) The Social Construction of Technological Systems : New Directions in the Sociology and History of Technology, Cambridge, MA: MIT Press, 17-50. [72] Suchman, L. (1995) Making work visible. Communications of the ACM 38(9), 56-64.

[73] Greenberg, S. \& Buxton, B. (2008) Usability evaluation considered harmful (some of the time). Proceedings of the SIGCHI conference on Human factors in computing systems, 111-120. [74] Fidel, R. (2012) Human Information Interaction: An Ecological Approach to Information Behavior. Cambridge, MA: The MIT Press.

[75] Franssila, J., H. \& Okkonen, J. (2013) Adjusting the design target of life-cycle aware HCI in knowledge work: focus on computing practices. In P. Campos, T. Clemmensen, J. A. Nocera, D. Katre, A. Lopes, \& R. Ørngreen, P. Campos, T. Clemmensen, J. A. Nocera, D. Katre, A. Lopes, \& R. Ørngreen (Eds.), Human Work Interaction Design: Work Analysis and HCI: Third IFIP WG 13.6 Working Conference, HWID 2012, Copenhagen, Denmark, December 5-6, 2012, Revised Selected Papers (pp. 150-160). Berlin, Heidelberg: Springer. 
Table 1. Studies with quantitative data about older adults' views on eHealth services $(n=10)$.

\begin{tabular}{|c|c|c|c|c|}
\hline $\begin{array}{l}\text { Authors, year, } \\
\text { country, discipline }\end{array}$ & Study focus & Research design & $\begin{array}{l}\text { Sample (age range; mean, } \\
\text { SD) }\end{array}$ & Findings \\
\hline $\begin{array}{l}\text { Ali et al. 2012 [37] } \\
\text { Malaysia } \\
\text { Visual informatics }\end{array}$ & $\begin{array}{l}\text { Digital, touch-screen } \\
\text { nutritional education } \\
\text { package (WE Sihat); } \\
\text { development, user } \\
\text { acceptance }\end{array}$ & User test; questionnaire & $\begin{array}{l}\text { Generally healthy }>60 \text { year- } \\
\text { olds }(60-76 ; \text { mean }=65.4+- \\
4.3), N=31\end{array}$ & $\begin{array}{l}\text { USES: - } \\
\text { ENABLERS: comprehensibility (understandable language), added value from the } \\
\text { digital format, ease of use } \\
\text { BARRIERS: comprehensibility (scientific terminology) } \\
\text { POSITIVE OUTCOMES: overall usefulness, increased knowledge, increase awareness } \\
\text { NEGATIVE OUTCOMES: - }\end{array}$ \\
\hline $\begin{array}{l}\text { Bol et al. 2013 [55] } \\
\text { Netherlands } \\
\text { Communication }\end{array}$ & $\begin{array}{l}\text { Cancer website; the } \\
\text { effects of } \\
\text { personalized audio- } \\
\text { visual information in } \\
\text { addition to text on } \\
\text { website satisfaction } \\
\text { and recall }\end{array}$ & $\begin{array}{l}\text { 3x2 experiment; } \\
\text { questionnaire } \\
\text { Website Satisfaction } \\
\text { Scale }\end{array}$ & $\begin{array}{l}\text { Lung cancer patients; } 128 \\
\text { younger (mean=54.19), } 103 \\
\text { older (mean=70.47) patients; } \\
(\text { Overall mean=61.32, } \\
\mathrm{SD}=10.76) ; \mathrm{N}=231\end{array}$ & $\begin{array}{l}\text { USES: - } \\
\text { ENABLERS: } \\
\text { BARRIERS: - } \\
\text { POSITIVE OUTCOMES: satisfaction (comprehensibility, attractiveness), emotional } \\
\text { support } \\
\text { NEGATIVE OUTCOMES: - } \\
\text { DIFFERENCES BY AGE: No differences in satisfaction between age groups; older } \\
\text { adults used Internet less; personalization increased satisfaction for emotional support in } \\
\text { both age groups. }\end{array}$ \\
\hline $\begin{array}{l}\text { Bol et al. 2014 [38] } \\
\text { Netherlands } \\
\text { Communication }\end{array}$ & $\begin{array}{l}\text { Cancer website; the } \\
\text { effect of adding } \\
\text { illustrations to online } \\
\text { health information on } \\
\text { website satisfaction } \\
\text { and information } \\
\text { recall }\end{array}$ & $\begin{array}{l}4 \times 2 \text { experiment; } \\
\text { questionnaire } \\
\text { Website Satisfaction } \\
\text { Scale }\end{array}$ & $\begin{array}{l}\text { Generally healthy younger } \\
\text { adults }<65 \text { years }(18-64 ; \text { mean } \\
47.47, \mathrm{SD}=15.61), \mathrm{n}=271 \\
\text { Generally healthy older adults } \\
\geq 65 \text { years }(65-85 ; \text { mean } 70.34 \\
\mathrm{SD}=4.33), \mathrm{n}=165 ; \mathrm{N}=436\end{array}$ & $\begin{array}{l}\text { USES: - } \\
\text { ENABLERS: } \\
\text { BARRIERS: } \\
\text { POSITIVE OUTCOMES: satisfaction (comprehensibility, attractiveness), emotional } \\
\text { support } \\
\text { NEGATIVE OUTCOMES: - } \\
\text { DIFFERENCES BY AGE: Older adults were more satisfied with the emotional support } \\
\text { offered by the website and less satisfied with its comprehensibility when compared to } \\
\text { younger adults; greater emotional satisfaction led to greater recall among older adults; } \\
\text { both age groups were more satisfied with the attractiveness when illustrations were } \\
\text { added. }\end{array}$ \\
\hline $\begin{array}{l}\text { Dillard \& Main } \\
2013 \text { [42] } \\
\text { US } \\
\text { Psychology }\end{array}$ & $\begin{array}{l}\text { Colon cancer health } \\
\text { messages; } \\
\text { Identification with a } \\
\text { personalized } \\
\text { testimonial character } \\
\text { and perceived } \\
\text { vividness of the } \\
\text { information }\end{array}$ & Questionnaire & $\begin{array}{l}\text { Generally healthy adults } 49-60 \\
(\mathrm{mean}=53, \mathrm{SD}=3.4), \mathrm{N}=1,266\end{array}$ & $\begin{array}{l}\text { USES: information seeking / learning } \\
\text { ENABLERS: relevant content of functionalities } \\
\text { BARRIERS: - } \\
\text { POSITIVE OUTCOMES: increased knowledge, increased behavioral intentions, } \\
\text { seeking contact with professionals (intentions to talk to a physician), information } \\
\text { seeking, positive emotional impact (positive mood) } \\
\text { NEGATIVE OUTCOMES: negative emotional impact (negative mood) }\end{array}$ \\
\hline $\begin{array}{l}\text { Hwang } 2011 \\
\text { Taiwan } \\
\text { Information } \\
\text { management }\end{array}$ & $\begin{array}{l}\text { A personalized e- } \\
\text { service; design, and } \\
\text { evaluation of } \\
\text { learnability, } \\
\text { perceived system } \\
\text { performance, } \\
\text { memorability and } \\
\text { satisfaction }\end{array}$ & $\begin{array}{l}\text { Trial (experimental vs. } \\
\text { control group); } \\
\text { questionnaire, task } \\
\text { observation }\end{array}$ & $\begin{array}{l}\text { Adults }+55 \text { years } \\
\text { (experimental group } \mathrm{n}=30, \\
\text { control group } \mathrm{n}=26 \text {; the } \\
\text { majority of study participants } \\
50-75 \text {-year-olds), } \mathrm{N}=56\end{array}$ & $\begin{array}{l}\text { USES: - } \\
\text { ENABLERS: added value, ease of use } \\
\text { BARRIERS: - } \\
\text { POSITIVE OUTCOMES: satisfaction } \\
\text { NEGATIVE OUTCOMES: - } \\
\text { DIFFERENCES BY AGE: A significant age-difference was found in satisfaction in the } \\
\text { control group using a traditional service but not in the experimental group; adults over } \\
67 \text { years were more satisfied with the traditional service than the younger participants } \\
\text { but both were more satisfied with the personalized service. }\end{array}$ \\
\hline
\end{tabular}




\begin{tabular}{|c|c|c|c|c|}
\hline & $\begin{array}{l}\text { access and use, } \\
\text { content preferences }\end{array}$ & & & $\begin{array}{l}\text { POSITIVE OUTCOMES: usefulness, improved communication with professionals } \\
\text { (help in preparing for a doctor's visit) } \\
\text { NEGATIVE OUTCOMES: negative emotional influence (anxiety) } \\
\text { DIFFERENCES BY AGE: Internet use declined with age }\end{array}$ \\
\hline $\begin{array}{l}\text { Medlock et al. }[48] \\
2013 \text { Netherlands } \\
\text { Medical informatics }\end{array}$ & $\begin{array}{l}\text { Online health } \\
\text { information seeking; } \\
\text { the consequences of } \\
\text { seeking online health } \\
\text { information }\end{array}$ & Questionnaire & $\begin{array}{l}\text { Seniors who use the internet } \\
(49-94, \text { mean }=72), N=100\end{array}$ & $\begin{array}{l}\text { USES: information seeking / learning } \\
\text { ENABLERS: - } \\
\text { BARRIERS: - } \\
\text { POSITIVE OUTCOMES: positive emotions (feeling reassured), increased knowledge, } \\
\text { impact on health behaviour, seeking contact with a professional, seeking information } \\
\text { NEGATIVE OUTCOMES: negative emotional influence (anxiety, confusion), strain } \\
\text { on patient-provider dialogue (questioned a treatment choice or a diagnosis, changed } \\
\text { medication without consulting a doctor) }\end{array}$ \\
\hline $\begin{array}{l}\text { Mira et al. } 2014[67] \\
\text { Spain } \\
\text { Health psychology / } \\
\text { Health services }\end{array}$ & $\begin{array}{l}\text { A tablet-based } \\
\text { education app; } \\
\text { design, } \\
\text { implementation, and } \\
\text { evaluation }\end{array}$ & RCT, experimental study & $\begin{array}{l}\text { Multimorbid, multimedication } \\
\text { patients }>65 \text { yr }(\text { control } \mathrm{n}=48 \\
\text { mean } 72.9, \mathrm{SD}=6 \text {; } \\
\text { experimental } \mathrm{n}=51 \text {, } \\
\text { mean }=70.9, \mathrm{SD}=8), \mathrm{N}=99\end{array}$ & $\begin{array}{l}\text { USES: - } \\
\text { ENABLERS: ease of use } \\
\text { BARRIERS: - } \\
\text { POSITIVE OUTCOMES: satisfaction, empowerment (sense of independence), } \\
\text { improved heath management } \\
\text { NEGATIVE OUTCOMES: - }\end{array}$ \\
\hline $\begin{array}{l}\text { Zettel-Watson \& } \\
\text { Tsukerman } 2016[53] \\
\text { US } \\
\text { Psychology }\end{array}$ & $\begin{array}{l}\text { Online health } \\
\text { management tools; }\end{array}$ & Questionnaire & $\begin{array}{l}\text { Generally healthy }>50 \text { y } \\
\text { competent computer users }(50- \\
87, \text { mean }=70.8, \mathrm{SD}=8.0) \\
\mathrm{N}=166\end{array}$ & $\begin{array}{l}\text { USES: social uses (information sharing), health management (in general, tracking), } \\
\text { personal information management (data management) } \\
\text { BARRIERS: non-familiarity, lack of additional benefits from use, lack of relevant } \\
\text { content or functionality, trust, usability issues, concerns on data loss } \\
\text { ENABLERS: help or support from others, ease of use, relevant content of functionality } \\
\text { POSITIVE OUTCOMES: overall usefulness, satisfaction, increased sense of control } \\
\text { and empowerment, increased knowledge, increased awareness, improved } \\
\text { communication with professionals, satisfaction, enhanced health management, time } \\
\text { saving, sense of security, continuity of care, increased confidence } \\
\text { NEGATIVE OUTCOMES: invasion of privacy, possibility of data loss, negative } \\
\text { emotional influence }\end{array}$ \\
\hline $\begin{array}{l}\text { \#18 Lam } \\
2011[61] \\
\text { US } \\
\text { Pharmacy }\end{array}$ & $\begin{array}{l}\text { Medication, } \\
\text { videoconferencing; } \\
\text { medication therapy } \\
\text { management (MTM) } \\
\text { services via } \\
\text { videoconferencing }\end{array}$ & $\begin{array}{l}\text { Questionnaire (post- } \\
\text { intervention); pre- } \\
\text { intervention } \\
\text { questionnaire to provide } \\
\text { information on } \\
\text { demographics and } \\
\text { medication adherence; } \\
4 \text { to } 6 \text { weeks follow-up } \\
\text { contact. }\end{array}$ & $\begin{array}{l}\text { Patients with e.g., } \\
\text { hypertension, diabetes } \\
\text { (mean=50.8, } \mathrm{SD}=11.5), \mathrm{N}=55\end{array}$ & $\begin{array}{l}\text { USES: social uses (communication), health management } \\
\text { ENABLERS: - } \\
\text { BARRIERS: - } \\
\text { POSITIVE OUTCOMES: satisfaction, increased awareness, changes in health } \\
\text { management } \\
\text { NEGATIVE OUTCOMES: - }\end{array}$ \\
\hline
\end{tabular}


Table 2. Studies with qualitative data about older adults' views on eHealth services $(n=14)$.

\begin{tabular}{|c|c|c|c|c|}
\hline $\begin{array}{l}\text { Authors, year, } \\
\text { country, discipline }\end{array}$ & Study focus & Research design & $\begin{array}{l}\text { Sample (age range; mean, } \\
\text { SD) }\end{array}$ & Findings \\
\hline $\begin{array}{l}\text { \#2 Ancker et al. } 2015 \\
\text { [66] US } \\
\text { Healthcare policy and } \\
\text { research / health } \\
\text { informatics }\end{array}$ & $\begin{array}{l}\text { Personal health records; } \\
\text { ways to track health data; } \\
\text { patients' and providers' } \\
\text { perceptions and use of } \\
\text { patient-tracked data }\end{array}$ & $\begin{array}{l}\text { Semi-structured } \\
\text { interviews \& grounded } \\
\text { theory / thematic } \\
\text { analysis }\end{array}$ & $\begin{array}{l}\text { Patients with Multiple } \\
\text { Chronic Conditions (MCC) } \\
(37-89, \text { mean=64.1), N=22, }\end{array}$ & $\begin{array}{l}\text { USES: social uses (communication), health management (in general, tracking, setting } \\
\text { goals, help in decision-making) } \\
\text { ENABLERS: - } \\
\text { BARRIERS: time and effort, non-familiarity } \\
\text { POSITIVE OUTCOMES: relevance, increased awareness (sense-making) } \\
\text { NEGATIVE OUTCOMES: negative emotional influence, judgmental language and } \\
\text { tone, distrust of data/information, subjective interpretation of information, time \& } \\
\text { effort }\end{array}$ \\
\hline $\begin{array}{l}\text { \#6 Brusoski \& Rosen } \\
{[58]} \\
2015 \text { US } \\
\text { Social work }\end{array}$ & $\begin{array}{l}\text { Tablets, health promotion; } \\
\text { learning to use tablet } \\
\text { technology and participate } \\
\text { in a psycho-educational } \\
\text { intervention using the } \\
\text { tablets' face-to-face video } \\
\text { program }\end{array}$ & $\begin{array}{l}\text { Qualitative case study, } \\
\text { intervention }\end{array}$ & $\begin{array}{l}\text { African American adults in } \\
\text { substance abuse treatment }>50 \\
(69,54,58), \mathrm{N}=3\end{array}$ & $\begin{array}{l}\text { USES: social uses (communication), health management (in general, setting goals, } \\
\text { reminders) } \\
\text { ENABLERS: added value (flexibility), help or support from others } \\
\text { BARRIERS: - } \\
\text { POSITIVE OUTCOMES: satisfaction, enjoyment, behaviour change, improved } \\
\text { communication with health professionals } \\
\text { NEGATIVE OUTCOMES: }\end{array}$ \\
\hline $\begin{array}{l}\text { \#14 Grindrod et al. } \\
2014[43] \\
\text { Canada } \\
\text { Pharmacy }\end{array}$ & $\begin{array}{l}\text { Mobile medication } \\
\text { management apps, user } \\
\text { perceptions }\end{array}$ & $\begin{array}{l}\text { Focus groups \& } \\
\text { grounded theory } \\
\text { (questionnaire data for } \\
\text { background } \\
\text { information) }\end{array}$ & $\begin{array}{l}\text { Adults }>50(52-78, \\
\text { mean }=67), \mathrm{N}=35\end{array}$ & $\begin{array}{l}\text { USES: seeking information / learning, health management (reminders) } \\
\text { ENABLERS: capability, interest, added value (tablet - could see the text) } \\
\text { BARRIERS: usability issues, comprehensibility (navigation, too much info), worries } \\
\text { of making a mistake, time and effort, cognitive issues, non-familiarity, "not for me", } \\
\text { lack additional benefits from use, approach to technology, lack of relevant content or } \\
\text { functionalities (incorrect assumptions on end users), not wanting to take responsibility } \\
\text { on decision-making } \\
\text { POSITIVE OUTCOMES: positive emotional influence, usefulness, increased } \\
\text { knowledge } \\
\text { NEGATIVE OUTCOMES: negative emotional influence, distrust of data/info, } \\
\text { possibility of data loss \& fallibility, time \& effort }\end{array}$ \\
\hline $\begin{array}{l}\# 19 \text { Le et al. } 2015 \\
{[46]} \\
\text { US } \\
\text { Biomedical } \\
\text { informatics / medical } \\
\text { education }\end{array}$ & $\begin{array}{l}\text { Visualization designs in } \\
\text { health monitoring systems; } \\
\text { evaluation }\end{array}$ & $\begin{array}{l}\text { Focus groups, content } \\
\text { analysis }\end{array}$ & $\begin{array}{l}\text { Adults }+62 \text { years } \\
\text { ('independent in activities of } \\
\text { daily living'), } N=30\end{array}$ & $\begin{array}{l}\text { USES: social uses (sharing information), health management (in general, tracking) } \\
\text { ENABLERS: - } \\
\text { BARRIERS: comprehensibility } \\
\text { POSITIVE OUTCOMES: - } \\
\text { NEGATIVE OUTCOMES: - }\end{array}$ \\
\hline $\begin{array}{l}\text { \#21 Lu et al. } 2014 \\
\text { [62] } \\
\text { Taiwan } \\
\text { Nursing }\end{array}$ & $\begin{array}{l}\text { Telehealth; consumers' } \\
\text { experiences with using } \\
\text { home telehealth care }\end{array}$ & $\begin{array}{l}\text { Focus groups \& } \\
\text { individual semi- } \\
\text { structured interviews, } \\
\text { qualitative content } \\
\text { analysis }\end{array}$ & $\begin{array}{l}\text { Older adults }(50-86 \\
\text { mean }=67) \text { with hypertension, } \\
\text { diabetes or both, } \mathrm{n}=12 \text { in } \\
\text { focus groups, } \mathrm{n}=8 \text { in } \\
\text { interviews, } \mathrm{N}=20\end{array}$ & $\begin{array}{l}\text { USES: social uses (communication, sharing information, feedback), health } \\
\text { management } \\
\text { ENABLERS: - } \\
\text { BARRIERS: costs } \\
\text { POSITIVE OUTCOMES: emotional support, sense of security, increased awareness, } \\
\text { enhanced health management, behaviour change } \\
\text { NEGATIVE OUTCOMES: distrust on data or information, being worried about } \\
\text { breakdown and fallibility }\end{array}$ \\
\hline $\begin{array}{l}\text { \#23 Martin-Hammond } \\
\text { et al. } 2015 \\
\text { [47] } \\
\text { US } \\
\text { Computing }\end{array}$ & $\begin{array}{l}\text { OTC medication selection } \\
\text { interface; design and } \\
\text { evaluation }\end{array}$ & $\begin{array}{l}\text { Prototype testing, } \\
\text { semi-structured } \\
\text { interviews, content } \\
\text { analysis }\end{array}$ & $\begin{array}{l}\text { Older adults }>65 \text { that had } \\
\text { purchased over-the-counter } \\
\text { medication }(65-75 ; \text { mean }=70 \text {, } \\
S D=3.1), N=7\end{array}$ & $\begin{array}{l}\text { USES: social uses (communication, sharing), health management (in general, } \\
\text { decision-making, recommendations) } \\
\text { ENABLERS: comprehensibility (simple language), added value (personalized content) } \\
\text { BARRIERS: usability issues, comprehensibility, lack of relevant content or } \\
\text { functionality } \\
\text { POSITIVE OUTCOMES: help in decision-making }\end{array}$ \\
\hline
\end{tabular}




\begin{tabular}{|c|c|c|c|c|}
\hline & & & & NEGATIVE OUTCOMES: - \\
\hline $\begin{array}{l}\# 28 \text { Scheibe et al. } \\
2015[63] \\
\text { Germany } \\
\text { Medicine / public } \\
\text { health }\end{array}$ & $\begin{array}{l}\text { mHealth; factors that } \\
\text { influence acceptance of } \\
\text { diabetes apps }\end{array}$ & $\begin{array}{l}\text { Guided interviews; app } \\
\text { testing, structured } \\
\text { content analysis }\end{array}$ & $\begin{array}{l}\text { Patients }>50 \text { with diabetes } \\
\text { types } 1 \text { or } 2,(\text { mean }=68.8 \\
\mathrm{SD}=8.2), \mathrm{N}=32\end{array}$ & $\begin{array}{l}\text { USES: Health management (in general, tracking, reminders) } \\
\text { ENABLERS: Interest (in technology) } \\
\text { BARRIERS: Lack of prior experience, lack of additional benefits, usability issues, fear } \\
\text { of making a mistake, fear of data loss, non-relevant content or functionality, lack of } \\
\text { help from others, health issues } \\
\text { POSITIVE OUTCOMES: - } \\
\text { NEGATIVE OUTCOMES: Possibility of data loss or fallibility }\end{array}$ \\
\hline $\begin{array}{l}\# 30 \text { Walker et al. } \\
2014[50] \\
\text { Australia } \\
\text { Occupational therapy }\end{array}$ & $\begin{array}{l}\text { Brain Fitness Program } \\
\text { (BFP), user experiences }\end{array}$ & $\begin{array}{l}\text { Intervention, journal, } \\
\text { semi-structured } \\
\text { interviews, weekly } \\
\text { phone contacts } \\
\text { (quantitative pre and } \\
\text { post measures for } \\
\text { cognition, quality of } \\
\text { life etc.) }\end{array}$ & $\begin{array}{l}\text { Generally healthy older adults } \\
\text { who completed a brain fitness } \\
\text { program (65-81), } \mathrm{N}=10\end{array}$ & $\begin{array}{l}\text { USES: - } \\
\text { ENABLERS: Interest, flexibility, meaningfulness/relevance } \\
\text { BARRIERS: "Not for me" (cultural inappropriateness of the content), time \& effort, } \\
\text { lack of additional benefits (no anticipated impact from use) } \\
\text { POSITIVE OUTCOMES: Positive emotional influence (enjoyment), impact in } \\
\text { thinking skills, increased confidence } \\
\text { NEGATIVE OUTCOMES: Negative emotional influence (frustration), lack of human } \\
\text { interaction }\end{array}$ \\
\hline $\begin{array}{l}\# 31 \text { Watkins \& Xie } \\
2015[51] \\
\text { US } \\
\text { Library and } \\
\text { information science }\end{array}$ & iPads for nutrition & $\begin{array}{l}\text { Focus group sessions, } \\
\text { grounded theory }\end{array}$ & $\begin{array}{l}\text { Older adults } \geq 60,(55 \% 60- \\
69,36 \% 70-79.2 \% 80 \text { or } \\
\text { older }), \mathrm{N}=22\end{array}$ & $\begin{array}{l}\text { USES: social uses (information sharing), health management (tracking, } \\
\text { recommendations) } \\
\text { ENABLERS: Familiarity, added value (flexibility, portability, tailored content), ease } \\
\text { of use } \\
\text { BARRIERS: Non-familiarity, "not for me”, costs, approach to technology (fear), fear } \\
\text { of losing the device } \\
\text { POSITIVE OUTCOMES: - } \\
\text { NEGATIVE OUTCOMES: - }\end{array}$ \\
\hline $\begin{array}{l}\text { \#32 Williams et al. } \\
2014[65] \\
\text { UK } \\
\text { Primary care health } \\
\text { sciences }\end{array}$ & $\begin{array}{l}\text { mHealth; patients' } \\
\text { expectations and } \\
\text { experiences }\end{array}$ & $\begin{array}{l}\text { Interviews; } \\
\text { pre-intervention for } \\
\text { background ( } \mathrm{n}=19) \text {, } \\
6 \text { mo post-intervention } \\
\text { for experiences on } \\
\text { mHealth application } \\
(\mathrm{n}=15) ; \text { grounded } \\
\text { theory }\end{array}$ & $\begin{array}{l}\text { Patients }>40 \text { with chronic } \\
\text { obstructive pulmonary disease } \\
(50-85, \text { mean=67), } \mathrm{N}=19\end{array}$ & $\begin{array}{l}\text { USES: social uses (communication, information sharing), health management (in } \\
\text { general, tracking, reminders) } \\
\text { ENABLERS: support, ease of use } \\
\text { BARRIERS: non-familiarity, "not for me" ("I'm too old"), health issues, reliance on } \\
\text { professionals as decision-makers } \\
\text { POSITIVE OUTCOMES: satisfaction, a sense of continuity of care, increased } \\
\text { awareness, enhanced health management (overall, reinforcing routines), increased } \\
\text { confidence } \\
\text { NEGATIVE OUTCOMES: time \& effort }\end{array}$ \\
\hline $\begin{array}{l}\# 33 \text { Woods et al. } \\
2013[54] \\
\text { US } \\
\text { Health services } \\
\text { research \& } \\
\text { development }\end{array}$ & $\begin{array}{l}\text { Electronic health records, } \\
\text { My HealtheVet, patients } \\
\text { views and experiences }\end{array}$ & $\begin{array}{l}\text { Focus groups, content } \\
\text { analysis }\end{array}$ & $\begin{array}{l}\text { Patients who had accessed the } \\
\text { PRH ( } \mathrm{n}=30) \text { and family } \\
\text { members }(\mathrm{n}=6),(49-82) \\
\mathrm{N}=36\end{array}$ & $\begin{array}{l}\text { USES: social uses (communication, information sharing, preparing for clinical visits), } \\
\text { health management (in general, scheduling, monitoring, reminders, help in decision- } \\
\text { making) } \\
\text { ENABLERS: - } \\
\text { BARRIERS: - } \\
\text { POSITIVE OUTCOMES: improved communication with professionals, increased } \\
\text { knowledge and awareness, enhanced health management, increased control and } \\
\text { empowerment), monitoring, help in decision-making, insight into providers' } \\
\text { perspectives, information seeking } \\
\text { NEGATIVE OUTCOMES: negative emotional influence (stress), technical problems, } \\
\text { mistakes and inconsistencies, subjective interpretation of information, judgmental } \\
\text { language and tone, invasion of privacy, strain on patient-provider dialogue }\end{array}$ \\
\hline $\begin{array}{l}\text { \#35 Young et al. } 2014 \\
\text { [52] US } \\
\text { Journalism \& mass } \\
\text { communication }\end{array}$ & $\begin{array}{l}\text { Personal health records; } \\
\text { perceptions of and } \\
\text { attitudes (barriers) toward } \\
\text { home-based health }\end{array}$ & $\begin{array}{l}\text { Semi-structured } \\
\text { interviews, content } \\
\text { analysis }\end{array}$ & $\begin{array}{l}\text { Generally healthy people (46- } \\
72), N=35\end{array}$ & $\begin{array}{l}\text { USES: social uses (communication, sharing information), information management, } \\
\text { health management (in general, planning) } \\
\text { ENABLERS: ease of use, needs (elicited by chronic illness, for example) } \\
\text { BARRIERS: approach to technology (technological discomfort), privacy and security }\end{array}$ \\
\hline
\end{tabular}




\begin{tabular}{|c|c|c|c|c|}
\hline & $\begin{array}{l}\text { information technology, } \\
\text { particularly personal EHRs }\end{array}$ & & & $\begin{array}{l}\text { concerns, lack of additional benefits "not for me" } \\
\text { POSITIVE OUTCOMES: - } \\
\text { NEGATIVE OUTCOMES: - }\end{array}$ \\
\hline $\begin{array}{l}\text { Kutz et al. } 2013 \text { [45] } \\
\text { USLibrary and } \\
\text { information science }\end{array}$ & $\begin{array}{l}\text { Making sense of mobile- } \\
\text { and web-based wellness } \\
\text { information technology }\end{array}$ & $\begin{array}{l}\text { Semi-structured } \\
\text { interviews, } \\
\text { visualizations to elicit } \\
\text { feedback } \\
\text { (questionnaire data for } \\
\text { background } \\
\text { information and } \\
\text { previous ICT } \\
\text { experience) }\end{array}$ & $\begin{array}{l}\text { Individuals across three } \\
\text { generations (young 18-25 } \\
(\mathrm{n}=7) \text {, middle-aged } 35-50 \\
(\mathrm{n}=7) \text {, older }>65(\mathrm{n}=7) \text { adults } \\
\mathrm{N}=21\end{array}$ & $\begin{array}{l}\text { USES: social uses (information sharing) } \\
\text { ENABLERS: familiarity } \\
\text { BARRIERS: privacy concerns, approach to technology } \\
\text { POSITIVE OUTCOMES: - } \\
\text { NEGATIVE OUTCOMES: - } \\
\text { DIFFERENCES BY AGE: } \\
\text { Younger adults were more likely to value broad information sharing; middle-aged and } \\
\text { older adults valued sharing information among intimate social relations. Younger } \\
\text { adults were familiar with the social networking features. Older adults were more likely } \\
\text { to take a passive approach to technology. Middle-aged adults stood out from the other } \\
\text { two groups in that they expressed concerns on health-tracking to their careers. }\end{array}$ \\
\hline $\begin{array}{l}\text { Price et al. } 2012[49] \\
\text { US } \\
\text { Psychology }\end{array}$ & $\begin{array}{l}\text { Electronic personal health } \\
\text { records; a needs analysis / } \\
\text { exploring perceptions of } \\
\text { usefulness }\end{array}$ & $\begin{array}{l}\text { Diaries, interviews; } \\
\text { grounded theory / top- } \\
\text { down enforcement of } \\
\text { categories }\end{array}$ & $\begin{array}{l}\text { Study } 1 \text { (diary) Younger } \\
\text { adults, } \mathrm{n}=19(18-20 \text {, } \\
\text { mean }=19, \mathrm{SD}=0.66) \text { and older } \\
\text { adults, } \mathrm{n}=24(61-83 \text {, } \\
\text { mean }=72, \mathrm{SD}=5.6), \mathrm{N}=43 \\
\text { Study } 2 \text { (interviews) Younger } \\
\text { adults, } \mathrm{n}=19(19-25 \text {, } \\
\text { mean }=20, \mathrm{SD}=1.52) \text { and older } \\
\text { adults, } \mathrm{n}=12(65-84, \\
\text { mean }=74, \mathrm{SD}=6.07), \mathrm{N}=31\end{array}$ & $\begin{array}{l}\text { USES: seeking information / learning, social uses (feedback), health management } \\
\text { (setting goals, planning, reminders, tracking, decision-making), information } \\
\text { management } \\
\text { ENABLERS: capability, prior experience, relevant content or functionality } \\
\text { BARRIERS: lack of additional benefits, lack of relevant content or functionalities, } \\
\text { privacy concerns, usability issues } \\
\text { POSITIVE OUTCOMES: increased knowledge, help in information management } \\
\text { NEGATIVE OUTCOMES: - } \\
\text { DIFFERENCES BY AGE: The information needs of the two populations differed } \\
\text { (e.g., symptoms, managing appointments); younger adults were more likely to use } \\
\text { online sources for health information and were more successful in finding relevant } \\
\text { information when doing so. Older adults were more likely to store information on test } \\
\text { results (also in digital format) and keep track on bills, for example, whereas younger } \\
\text { adults were more likely to keep track on symptoms. Older adults preferred to be in } \\
\text { control of entering information on the system whereas younger adults were more } \\
\text { likely to share this responsibility with a doctor. Older adults more willing to share info } \\
\text { with family members. }\end{array}$ \\
\hline
\end{tabular}


Table 3. Studies with qualitative \& quantitative data about older adults' views on eHealth services $(n=8)$.

\begin{tabular}{|c|c|c|c|c|}
\hline Authors, year, country & Study focus & Research design & Sample (age range; mean, SD) & Findings \\
\hline $\begin{array}{l}\text { Burns et al. } 2013 \text { [59] } \\
\text { Australia } \\
\text { Social sciences }\end{array}$ & $\begin{array}{l}\text { AsthmaWise; usability } \\
\text { assessment and } \\
\text { improvement }\end{array}$ & Think-aloud; questionnaire & $\begin{array}{l}\text { People with asthma }(57-86, \\
\text { mean }=65.8), \mathrm{N}=13\end{array}$ & $\begin{array}{l}\text { USES: - } \\
\text { ENABLERS: service attractiveness, comprehensibility (ease of finding } \\
\text { information and reading; use of jargon), ease of use } \\
\text { BARRIERS: comprehensibility, lack of relevant content of functionality } \\
\text { POSITIVE OUTCOMES: usefulness, increased knowledge, increased } \\
\text { awareness, enhanced health management } \\
\text { NEGATIVE OUTCOMES: - }\end{array}$ \\
\hline $\begin{array}{l}\text { Chun \& Patterson } 2012 \\
\text { [39] } \\
\text { US } \\
\text { Industrial engineering }\end{array}$ & $\begin{array}{l}\text { Internet-based } \\
\text { telemedicine system } \\
\text { "My HealtheVet"; } \\
\text { usability testing, } \\
\text { identification of } \\
\text { differences in } \\
\text { performance and } \\
\text { satisfaction between } \\
\text { younger and older adults, } \\
\text { and interface factors that } \\
\text { cause those differences }\end{array}$ & $\begin{array}{l}\text { Questionnaire, interviews } \\
\text { + usability measures (task } \\
\text { completion) }\end{array}$ & $\begin{array}{l}\text { Young adults } \mathrm{n}=10(24-33 \\
\text { mean }=27.6, \mathrm{SD}=3.10) \text {; older } \\
\text { adults } \mathrm{n}=6(54-73, \text { mean }=61.2 \\
\mathrm{SD}=6.95, \mathrm{~N}=16\end{array}$ & $\begin{array}{l}\text { USES: social uses (communication), health management (in general, } \\
\text { information seeking / learning) } \\
\text { ENABLERS: ease of use, support information } \\
\text { BARRIERS: lack of relevant content or functionality (help functions), } \\
\text { comprehensibility (organization \& structure) } \\
\text { POSITIVE OUTCOMES: satisfaction } \\
\text { NEGATIVE OUTCOMES: } \\
\text { DIFFERENCES BY AGE: When compared to younger adults, older } \\
\text { adults tended to be more highly and easily satisfied once they had } \\
\text { successfully completed given tasks. Older adults had more difficulties in } \\
\text { finding information and tended to blame themselves rather than the } \\
\text { service features in case problems occurred. }\end{array}$ \\
\hline $\begin{array}{l}\text { Cristancho-Lacroix et al. } \\
2014[40] \\
\text { France } \\
\text { Gerontology }\end{array}$ & $\begin{array}{l}\text { A web-based program } \\
\text { for caregivers of people } \\
\text { with Alzheimer's } \\
\text { disease; development }\end{array}$ & $\begin{array}{l}\text { Usability tests, think-aloud, } \\
\text { interviews \& questionnaire }\end{array}$ & $\begin{array}{l}\text { Health care professionals, } \\
\text { caregivers, spouses, healthy } \\
\text { older adults, healthy volunteers } \\
+60, \mathrm{~N}=49\end{array}$ & $\begin{array}{l}\text { USES: - } \\
\text { ENABLERS: Ease of use, attractiveness, comprehensibility } \\
\text { BARRIERS: lack of prior experience, comprehensibility, "not for me" } \\
\text { (not seeing oneself as a target for gerontechnology) } \\
\text { POSITIVE OUTCOMES: satisfaction } \\
\text { NEGATIVE OUTCOMES: - }\end{array}$ \\
\hline $\begin{array}{l}\text { Currie et al. } 2015[60] \\
\text { Scotland } \\
\text { Geosciences }\end{array}$ & $\begin{array}{l}\text { Technology in health } \\
\text { care; attitudes, current } \\
\text { use, and acceptance }\end{array}$ & Questionnaires \& interviews & $\begin{array}{l}\text { People with } \\
\text { chronic pain }(25-86, \text { mean=60), } \\
N=168 / 11\end{array}$ & $\begin{array}{l}\text { USES: health management (in general, seeking information / learning) } \\
\text { ENABLERS: added value from digital format, ease of use } \\
\text { BARRIERS: cognitive \& health issues; infra, technical issues } \\
\text { POSITIVE OUTCOMES: increased knowledge, health management } \\
\text { NEGATIVE OUTCOMES: isolation, time \& effort }\end{array}$ \\
\hline $\begin{array}{l}\text { Dhillon et al. } \\
2016 \text { [41] } \\
\text { New Zealand } \\
\text { Information systems }\end{array}$ & $\begin{array}{l}\text { Health management } \\
\text { system Healthcare4life; } \\
\text { design and feasibility } \\
\text { assessment }\end{array}$ & $\begin{array}{l}\text { Questionnaires \& interviews; } \\
\text { quantitative measures pre- } \\
\text { interim-post intervention; } \\
\text { interview at the end of the study }\end{array}$ & $\begin{array}{l}\text { Seniors }(60-85, \text { mean } 79, \\
\mathrm{SD}=17.68), \\
60-69(\mathrm{n}=12) \text { vs. } 70-85(\mathrm{n}=12), \\
\mathrm{N}=43\end{array}$ & $\begin{array}{l}\text { USES: health management, social uses (communication) } \\
\text { ENABLERS: ease of use } \\
\text { BARRIERS: time and effort, lack of relevant content or functionality } \\
\text { POSITIVE OUTCOMES: usefulness, increase awareness, enhanced } \\
\text { health management, overall positive impact in life } \\
\text { NEGATIVE OUTCOMES: negative emotions about social networking } \\
\text { functionalities } \\
\text { DIFFERENCES BY AGE: Older adults (60-69-year-olds) were more } \\
\text { likely to perceive themselves as competent and find the service more } \\
\text { valuable than the older participants. }\end{array}$ \\
\hline $\begin{array}{l}\text { Hong et al. } 2014[56] \\
\text { US } \\
\text { Public health }\end{array}$ & $\begin{array}{l}\text { PA promotion; usability } \\
\text { and acceptability testing }\end{array}$ & $\begin{array}{l}\text { 1. acceptability testing with a } \\
\text { user-experience survey (ease of } \\
\text { use, helpfulness, satisfaction); } \\
\text { qualitative and quantitative data; }\end{array}$ & $\begin{array}{l}\text { Cancer survivors }+ \text { other } \\
\text { diseases }(60-82, \text { mean }=88.0 \text {, } \\
\mathrm{SD}=6.3), \mathrm{N}=33\end{array}$ & $\begin{array}{l}\text { USES: social uses (communication), health management (planning \& } \\
\text { scheduling, tracking, reminders) } \\
\text { ENABLERS: awareness (that the service exists), having the technical } \\
\text { equipment, prior experience, ease of use }\end{array}$ \\
\hline
\end{tabular}




\begin{tabular}{|c|c|c|c|c|}
\hline & & $\begin{array}{l}\text { 2. usability testing: task } \\
\text { completion measures \& } \\
\text { documentation of user } \\
\text { comments during the test; } \\
\text { qualitative and quantitative data }\end{array}$ & & $\begin{array}{l}\text { BARRIERS: usability issues, lack of added value } \\
\text { POSITIVE OUTCOMES: usefulness behaviour change } \\
\text { NEGATIVE OUTCOMES: - }\end{array}$ \\
\hline $\begin{array}{l}\text { Mira et al. } \\
2015[68] \\
\text { Spain } \\
\text { Health psychology }\end{array}$ & $\begin{array}{l}\text { Medication app; design, } \\
\text { development, and } \\
\text { assessment }\end{array}$ & Questionnaires \& meetings & Patients $(68.8, \mathrm{SD} 8.3), \mathrm{N}=61$ & $\begin{array}{l}\text { USES: - } \\
\text { ENABLERS: comprehensibility (language easy to understand) } \\
\text { BARRIERS: - } \\
\text { POSITIVE OUTCOMES: satisfaction, usefulness } \\
\text { NEGATIVE OUTCOMES: - }\end{array}$ \\
\hline $\begin{array}{l}\text { Young et al. } \\
2011 \text { [64] } \\
\text { US } \\
\text { Comprehensive access } \\
\text { and delivery research } \\
\text { and evaluation }\end{array}$ & $\begin{array}{l}\text { Telehealth; aspects of } \\
\text { home telehealth pose } \\
\text { challenges and } \\
\text { frustrations for the } \\
\text { population of aging } \\
\text { veterans }\end{array}$ & Questionnaires \& interviews & $\begin{array}{l}\text { Veterans with diabetes, } \\
\text { hypertension, high cholesterol } \\
(55-87 \text {, mean }=72.6, \mathrm{SD}=9.5) \text {, } \\
\mathrm{N}=25\end{array}$ & $\begin{array}{l}\text { USES: health management (in general, planning \& scheduling, tracking, } \\
\text { reminders, seeking information / learning), social uses (communication, } \\
\text { feedback) } \\
\text { ENABLERS: ease of use (instructions) } \\
\text { BARRIERS: usability issues } \\
\text { POSITIVE OUTCOMES: increased knowledge, enhanced health } \\
\text { management, behaviour change } \\
\text { NEGATIVE OUTCOMES: - }\end{array}$ \\
\hline
\end{tabular}




\title{
Summary table
}

\author{
What was already known on the topic \\ - eHealth research tends to focus either on intervention effectiveness or system usability \\ - The usefulness, purposes, benefits, or value of eHealth services to their users have been less \\ examined \\ - Older adults are the fastest growing group of Internet users but likely to be excluded from the \\ benefits of eHealth services \\ - This exclusion has been associated with a lack of access to digital services but also to a lack of \\ use

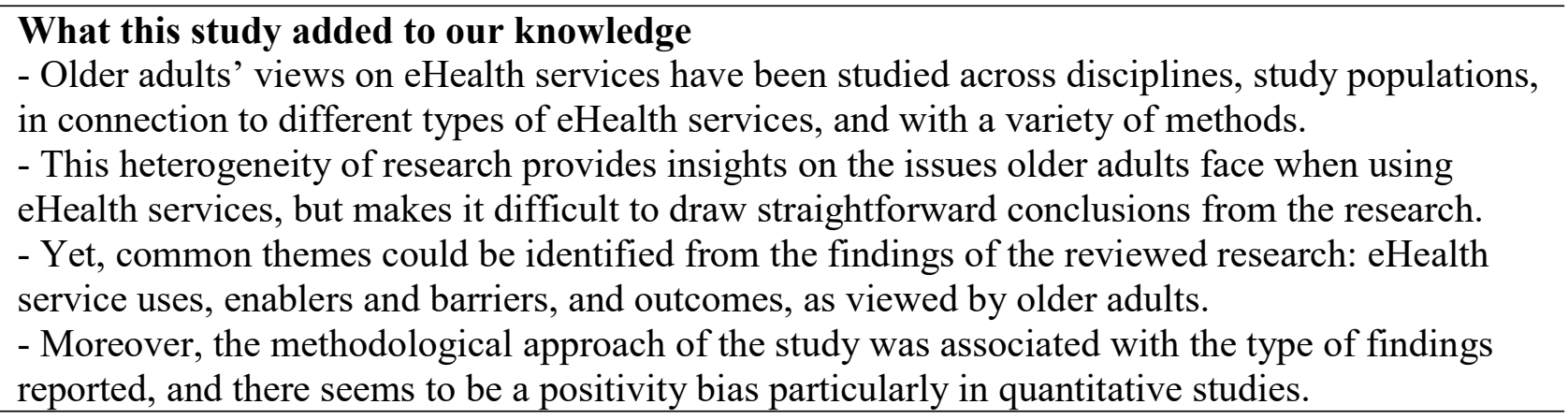

